\title{
Is the indonesian regulation of standard level of service of a pedestrian path fulfill pedestrians' convenience
}

\author{
Amirotul Mahmudah ${ }^{1, *}$, Slamet Legowo ${ }^{2}$, Agus Sumarsono ${ }^{3}$, Studyamadyakomunika Linta ${ }^{4}$, and Benny Irawan ${ }^{5}$ \\ 1,2,3 Lecturer of Civil Engineering Study Program, Universitas Sebelas Maret, Surakarta 57126, Indonesia \\ ${ }^{4,5}$ Graduates of Civil Engineering Study Program, Universitas Sebelas Maret, Surakarta 57126, Indonesia
}

\begin{abstract}
Indonesia published Regulation No: 03/PRT/M/2014 about the Pedestrian Level of Service (LOS), consist of pedestrian movement characteristics and sidewalk capacity, as like the Bangkok standard, there is no parameter that represents pedestrian interest. Australian standards develop a Level of Service with the main based on categories that relate with pedestrian convenience. Within this study, identifying Indonesian pedestrian interests done by measuring pedestrian perception of convenience. This study aims to check the suitability between this standard pedestrian LOS and pedestrian perception of convenience in a commercial area, Pasar Gede market. The study results, based on Indonesia regulation LOS, the pedestrian path around Pasar Gede market is categorized as level A at all sections, and this is the same as the Bangkok standards. According to the Australian's standard, the LOS is an A for the West section, B for the North section, and C for the South section. The pedestrians have perceptions of moderately discomfort for all sections. This means that although the pedestrian path fulfills the level of service for Indonesian Government regulation, it does not fulfill user satisfaction. Therefore, the Indonesian LOS standard for pedestrian paths doesn't provide equity for the pedestrian.
\end{abstract}

\section{Introduction}

Walking is a significant mode of transport to promote sustainable transport, since it doesn't need fuel does not create any pollution, and improves health $[1,2]$. One parameter to value pedestrian path performance is Level of Service. Countries have formulated standards of level of service for pedestrian paths, and each country has its own factors and values, which depend on pedestrian characteristics.

A standard Level of Service (LOS) is really important for planning, evaluation, and improvement processes. LOS is used as a standard for the planners to design to, and a suitable LOS and user perception is key to the successful implementation of the design. Pedestrian LOS have been discussed since around 1983 by A. Polus [3], but is still a hot topic of discussion $[4,5,6,7,8]$. Discussion about the LOS for pedestrian path starts with the flow, speed characteristics, and sidewalk capacity, and continues with pedestrian facilities, and then pedestrian perception. Considering the right factors for the LOS should meet the satisfaction of planners and users. At this time, there are various approaches to pedestrian level of service models. Some of them emphasize pedestrian flow and volume, as well as sidewalk capacity, and others consider pedestrian path facilities [4]. Most of the guidelines consider that pedestrian flow and volume, as well as sidewalk capacity is enough to measure LOS, but this consideration is criticized because pedestrians are then treated like vehicles [4].

Other studies discuss pedestrian perception for the LOS $[5,6]$, and mention that having a good understanding of the pedestrian perception of LOS on a pedestrian path in an urban area can be useful in developing strategies for providing a comfortable and safe walking environment [5]. Kang et al. [5] concludes that the most influence factor on LOS value is pedestrian flow rates, however, many other factors have a significant influence on LOS perception, including sidewalk width, the presence of a barrier separating the sidewalk from motor-vehicle traffic, the presence of parking next to the sidewalk, and so on. Jena [6] suggests that pedestrian flow and volume, and te sidewalk capacity are most important and so it is reasonable for these to be the main point to value in the LOS. But there are many other facilities that pedestrians also consider important when they evaluate LOS. Other researchers use a rating system to analyze the LOS, based on road users' 5 -factor perception: safety, comfort level, vendor encroachment, accessibility and sidewalk performance, and climate conditions.

Comparison and evaluation among methodologies at international level for the estimation of pedestrian levels of service conclude that current methodologies are unable to analyze the entire spectrum of the 
walking experience, and also conclude that no method is universally applicable $[7,8]$, so there is a need to define a specific model as a standard pedestrian LOS for each country. Based on the identification of the weakness of existing methodologies, Christopoulou and Latinopoulou [7] developed a model whose factors reflect the pedestrian LOS along Greek urban streets. The factors are developed from 3 categories: that is, traffic parameters, geometry/environmental/sidewalk parameters, and pedestrian movement parameters. Then the model is calibrated with a questionnaire survey to pedestrians, residents, and transport experts. Shingh and Jain [8] conclude that assessment methods should not only be driven by data that can be easily measured and manipulated quantitatively, but should also include the walking experience of pedestrian and planners.

In the Indonesian case, pedestrian facilities are not as good as in developed countries. The climate and weather conditions (tropical country, high temperature and humidity), public transport performance, and private vehicle use discourage the willingness to walk, and define a specific pedestrian characteristic. At this time, walking is a choice at most for captive people. Some research on pedestrian LOS discusses a walkability index [9], which can be used to identify improvements to the pedestrian way according to pedestrian perceptions. Sutikno et al. [9] measured a walkability index of Sukarno-Hatta street corridor, business corridor, in Malang city, East Java, Indonesia. They used 9 factors: physical condition of the pedestrian way; conflict with the street/accident; ease of crossing; maintenance and completeness of supporting facilities; effective width of pedestrian way; buffer with the street; accessibility of the pedestrian way; physical aesthetic of pedestrian way; and shade. Based on these factors, the respondents' value given to the walkability index of the SukarnoHatta street corridor was medium. The study also discussed pedestrian perception that the pedestrian facilities need to be improved; i.e. continued improvement and addition of pedestrian ways, planting plans that can reduce air pollution, availability of crossings, the addition of shadeproviding trees, traffic management to reduce congestion, and parking design. Other studies discuss the pedestrian LOS model incorporating pedestrian perceptions of sidewalks with vendor activities [10]. One model was developed for a commercial area in Jakarta, based on 4 dependent variables-comfort, vendor problems, pedestrian volume, interaction with vendors - with a multiple linear regression model. Comfort has the highest influence on pedestrian LOS, followed by vendor problems, vendor interaction, and pedestrian volume. As far as the author knows, until now there has been no discussion about suitability between the existing Government regulation and pedestrian perception. This is the aim of this study.

In 2014 the Public Works Minister of Indonesia published a regulation about pedestrian level of service in Regulation No: 03/PRT/M/2014 [11]. This regulation uses pedestrian movement as its parameter.
The regulation will be applied to a commercial area, since the commercial area is an important land use to support economic growth. One of important supporting infrastructures in the commercial area is a pedestrian path, which is there for the municipality to address pedestrian satisfaction on the pedestrian level of service. This regulation divides LOS into 6 levels: $\mathrm{A}, \mathrm{B}, \mathrm{C}, \mathrm{D}, \mathrm{E}$, and $\mathrm{F}$ [11], as well as other standards $[12,13] . A$ is the most comfortable pedestrian environment, whereas and $\mathrm{F}$ is the least comfortable pedestrian environment. The Indonesian standard LOS is based on pedestrian space, average speed, flow rate, and volume capacity ratio (VCR). Within this study the pedestrian LOS and comfort based on pedestrian perception of the pedestrian path facilities at Pasar Gede market will be measured. During the survey, this facility is a new facility. Based on survey data will be analyzed and discussed the value of LOS based on area, flow rate, and volume capacity ratio is fulfil the planner design. And also measured does the facility fulfil the pedestrian convenience. Then the LOS based on Indonesian regulation also will be compared with the pedestrian path LOS for Thailand and Australia.

The study results hope to show the differences among the LOS based on Regulation No. 03/PRT/M/2014, Bangkok, and Australian standards, and also the value of pedestrian perception on pedestrian path facilities in Pasar Gede Market. The discussion results can be show the difference level of satisfaction between planner and pedestrian. This proof can be based on consideration that it is really important to use factors on pedestrian convenience in LOS.

\section{Research Method}

\subsection{Field Location}

Pasar Gede market is the oldest traditional market that serves the daily needs of downtown Surakarta. The market has multiple functions, and as well as a commercial area it has also become a tourist destination. To support this strategic function, the Government needs to provide good infrastructure facilities such as the pedestrian paths that fulfill the desired level of convenience for the pedestrian.

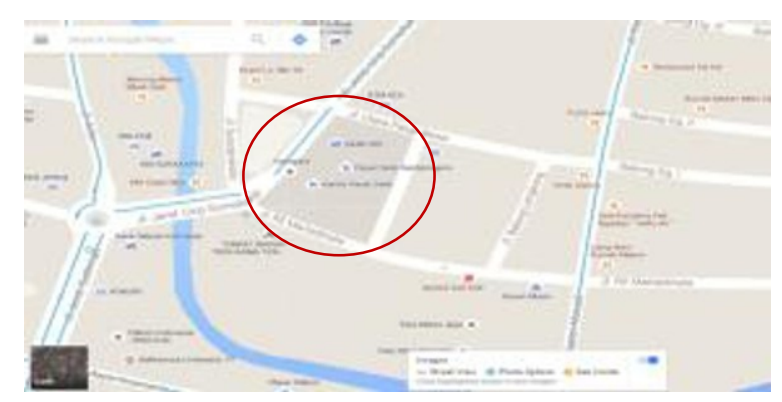

Fig 1 Pasar Gede Market 
As be seen in Figure 1, Pasar Gede market is surrounded by Urip Sumoharjo Street, RE Martadinata Street, and Utara Pasar Besar Street. Pedestrian path is located between these streets, and the market consists of 4 sections of pedestrian path: North, West, South, and east sections. Each section has a different geometrical design and facilities so they need to be analyzed separately. The operational hours of the market are 07:00-16:00 Western Indonesia Time (WIB). During the survey was conducted the east side used as warehouse, so we do not analyze this section.

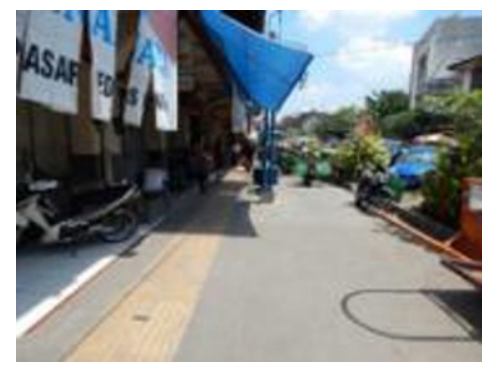

2. a. West section

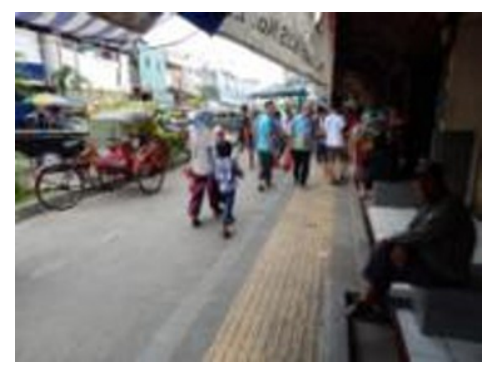

2.b. North section

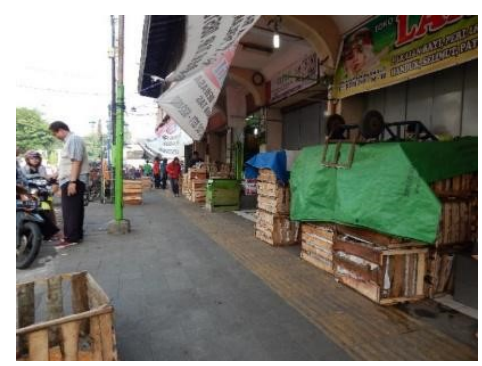

2.c. South section

Fig 2. Pedestrian path in Pasar Gede market

Table 1. Geometry and surface conditions of pedestrian path in Pasar Gede market

\begin{tabular}{ccc}
\hline Section & $\begin{array}{c}\text { Effective Width } \\
\text { (meters) }\end{array}$ & Quality of path surface \\
\hline North & 4 & $\begin{array}{c}\text { Continuous, smooth, skid- } \\
\text { resistant surface, without cracks } \\
\text { and bumps }\end{array}$ \\
\hline South & 2,5 & $\begin{array}{c}\text { Continuous, smooth, skid- } \\
\text { resistant surface, without cracks } \\
\text { and bumps }\end{array}$ \\
\hline West & 2,7 & $\begin{array}{c}\text { Continuous, smooth, skid- } \\
\text { resistant surface, without cracks } \\
\text { and bumps }\end{array}$ \\
\hline
\end{tabular}

\subsection{Pedestrian Flow Survey}

Corresponding author: amirotulmhm@staff.uns.ac.id
First, the preliminary survey is conducted. This survey aims to determine the observation points to represent the flow and speed conditions along the section, to define the survey method, survey time, and also to design the number and tasks of the surveyors. Second, based on a preliminary survey, the main survey is conducted during operational hours to collect pedestrian flow and speeds, with an observation span of $10 \mathrm{~m}$ for each section. The data were collected during operational hours at 5-minute intervals. The manual survey is done by 9 surveyors for all sections. The total number of pedestrians during survey periods was 8559 persons. Based on this data, it can be calculated pedestrian density, speed, and flow.

\subsection{Greenberg model}

The capacity of a pedestrian path can be calculated based on the Greenshield, Greenberg, or Underwood models. The appropriate application of these models depends on the pedestrian movement characteristics. Analog with pedestrians behavior in Yogyakarta, we assume that in Surakarta the appropriate model for pedestrian flow characteristics is the Greenberg model [14].

\subsection{LOS Standard}

The performance of the facilities is usually measured in the Level of Service and the standard of LOS is defined by the Government. In Indonesia the regulation of standard LOS for the pedestrian path is done by the Ministry of Public Works, on "Pedoman Perencanaan, Penyediaan, dan Pemanfaatan Prasarana dan Sarana Jaringan Pejalan Kaki di Kawasan Perkotaan," according to regulation number No: 03/ PRT/M/2014 [7]. The LOS standard includes 4 parameters: Area, Speed, Flow, and the Volume Capacity Ratio, as mentioned in Table 1. The manual for the planning process, whereby the facilities fulfill the LOS-A, should fulfill the planning standard and satisfy the users; in this case, the users are pedestrians.

Table 2. Standard of Pedestrian Path LOS in Ministry of Public Works Regulation No: 03/PRT/M/2014

\begin{tabular}{ccccc}
\hline LOS & $\begin{array}{c}\text { Area } \\
\left(\mathbf{m}^{2} / \mathbf{p e d}\right)\end{array}$ & $\begin{array}{c}\text { Speed } \\
(\mathbf{m} / \mathbf{m i n u t e})\end{array}$ & $\begin{array}{c}\text { Flow } \\
\text { (ped/meter/ } \\
\text { minute) }\end{array}$ & $\begin{array}{c}\text { Volume } \\
\text { Capacity } \\
\text { Ratio } \\
\text { (VCR) }\end{array}$ \\
\hline $\mathrm{A}$ & $\geq 12$ & $\geq 78$ & $\leq 6.7$ & $\leq 0.08$ \\
\hline $\mathrm{B}$ & $\geq 3.6$ & $\geq 75$ & $\leq 23$ & $\leq 0.28$ \\
\hline $\mathrm{C}$ & $\geq 2.2$ & $\geq 72$ & $\leq 33$ & $\leq 0.40$ \\
\hline $\mathrm{D}$ & $\geq 1.4$ & $\geq 68$ & $\leq 50$ & $\leq 0.60$ \\
\hline $\mathrm{E}$ & $\geq 0.5$ & $\geq 45$ & $\leq 83$ & $\leq 1.00$ \\
\hline $\mathrm{F}$ & $<0.5$ & $<45$ & variable & 1.00 \\
\hline
\end{tabular}

Bangkok developed its standard LOS for walkways based on space and flow. Comparison between Bangkok and Indonesian standards shows that space in Indonesia standards is higher than Bangkok, and Flow for Indonesian standards is lower than Bangkok standards. This means that Bangkok pedestrians can tolerate and occupy less personal space than Indonesian pedestrians. 
Table 3. Developed LOS Bangkok standard for walkways in Bangkok

\begin{tabular}{ccc}
\hline LOS & Space $\left(\mathbf{m}^{\mathbf{2}} / \mathbf{p e d}\right)$ & Flow $(\mathbf{p e d} / \mathbf{m} / \mathbf{m i n})$ \\
\hline $\mathrm{A}$ & $\geq 2.38$ & $\leq 28$ \\
\hline $\mathrm{B}$ & $1.60-2.38$ & $28-40$ \\
\hline $\mathrm{C}$ & $0.98-1.60$ & $40-61$ \\
\hline $\mathrm{D}$ & $0.66-0.98$ & $61-81$ \\
\hline $\mathrm{E}$ & $0.37-0.66$ & $81-101$ \\
\hline $\mathrm{F}$ & $\leq 0.37$ & 101 or variable \\
\hline
\end{tabular}

The Government of Western Australia composed guidelines for assessing the pedestrian level of service [13]. Factors affecting the pedestrian level of service are physical characteristics, location factors, and user factors. Methods of assessment are explained in Table 3. The guidelines also provide a pedestrian level of service assessment sheet which explains the weight and definition of each point. Each factor is assessed and then multiplied by the score, then the final weight score of each factor is summed and plotted, as shown in Table 4.

Table 4. Methods of Assessment

\begin{tabular}{|c|c|c|}
\hline Category & LOS Factor & Method of Assessment \\
\hline \multirow{6}{*}{$\begin{array}{l}\text { Physical } \\
\text { Characteris } \\
\text { tics }\end{array}$} & Access & Examine on site \\
\hline & Path Width & $\begin{array}{l}\text { Measure from plans or } \\
\text { during site visit }\end{array}$ \\
\hline & $\begin{array}{l}\text { Surface } \\
\text { Quality }\end{array}$ & Examine during site visit \\
\hline & $\begin{array}{l}\text { Crossing } \\
\text { Opportunities }\end{array}$ & Assess during site visit \\
\hline & $\begin{array}{l}\text { Support } \\
\text { Facilities }\end{array}$ & Examine during site visit \\
\hline & Connectivity & $\begin{array}{l}\text { Assess from street } \\
\text { directory maps } \\
\text { and during site } \\
\text { visit }\end{array}$ \\
\hline \multirow[t]{2}{*}{$\begin{array}{l}\text { Location } \\
\text { Factors }\end{array}$} & $\begin{array}{l}\text { Path } \\
\text { Environment }\end{array}$ & $\begin{array}{l}\text { Assess from street } \\
\text { directory maps } \\
\text { and during site } \\
\text { visit }\end{array}$ \\
\hline & $\begin{array}{l}\text { Potential for } \\
\text { Vehicle } \\
\text { Conflict }\end{array}$ & $\begin{array}{l}\text { Count during site visit } \\
\text { (number per km) }\end{array}$ \\
\hline \multirow[t]{3}{*}{$\begin{array}{l}\text { User } \\
\text { Factors }\end{array}$} & $\begin{array}{l}\text { Path User } \\
\text { Volume }\end{array}$ & $\begin{array}{l}\text { Local Government } \\
\text { statistics or count during } \\
\text { site visit }\end{array}$ \\
\hline & $\begin{array}{l}\text { Mix of Path } \\
\text { Users }\end{array}$ & Count during site visit \\
\hline & $\begin{array}{l}\text { Personal } \\
\text { Security }\end{array}$ & $\begin{array}{l}\text { Assess during site visit, } \\
\text { preferably at night }\end{array}$ \\
\hline
\end{tabular}

Table 5. LOS grade scale

\begin{tabular}{ccc}
\hline $\begin{array}{c}\text { LOS } \\
\text { Grade }\end{array}$ & Description & Range of Scores \\
\hline A & Ideal & 132 or higher \\
\hline B & Reasonable & $101-131$ \\
\hline C & Basic & $69-100$ \\
\hline
\end{tabular}

\begin{tabular}{ccc}
\hline D & Poor & $37-68$ \\
\hline E & Unsuitable & 36 or lower \\
\hline F & Problems with & Score of less than 15 \\
& Access & for Access \\
\hline
\end{tabular}

\subsection{Questionnaire survey}

Within this research, the survey method used to collect pedestrian perceptions about pedestrian path facilities is a questionnaire survey. The error tolerance is $10 \%$, To fulfill the data adequacy test, from the population number (for the number of visitors in 1- day during operational hours) is 8559 persons, the total respondents needed is 288: 97 respondents for the West section; 98 for the North section; and 93 respondents for the South section.

Reference [15] mentions that pedestrian comfort is influenced by the following factors: circulation, weather, noise, smell, landscape furniture, safety, cleanliness, and appearance. Within this study, safety is divided into 2 variables: safety from crime and safety of the pedestrian path (slippery, sloping, potholes), and 1 variable is added: completeness of supporting facilities. The response in the questionnaire for each factor is designed using a Likert scale. Percentage class interval is built based on score assessment.

Table 6. Comfort Criteria based on score assessment

Interval Kelas Persentase Criteria

(\%)

\begin{tabular}{cc}
\hline $100 \% \geq$ Percentage $>84 \%$ & Strongly comfort \\
\hline $84 \% \geq$ Percentage $>68 \%$ & Moderately comfort \\
\hline $68 \% \geq$ Percentage $>52 \%$ & Slightly comfort \\
\hline $52 \% \geq$ Percentage $>36 \%$ & Moderately discomfort \\
\hline $36 \% \geq$ Percentage $>20 \%$ & Strongly discomfort \\
\hline
\end{tabular}

To guarantee that the questions in questionnaire are valid and reliable, the questionnaire is analyzed the valid and reliable based on Pearson Correlation and Spearmen Brown theory, as in [16].

\section{Result And Discussion}

Geometric and pavement conditions of the pedestrian path at Pasar Gede market are in good condition since it was built in the same year as the study. Each section has a different effective width, as seen in Table 1, so it is reasonable to calculate the pedestrian path LOS separately for each section.

\subsection{Pedestrian Flow, Speed, and Density}

The pedestrian path at Pasar Gede Market has specific characteristics since its location is really close to shops, so as pedestrians walk to their destination, they usually also glimpse the merchandise in the shops. Based on this condition it is reasonable to omit speed for categorizing the level of service (LOS). 
Table 7. Movement characteristics of pedestrians in pedestrian path at Pasar Gede market

\begin{tabular}{lccc} 
& $\begin{array}{c}\text { North } \\
\text { Section }\end{array}$ & $\begin{array}{c}\text { South } \\
\text { Section }\end{array}$ & $\begin{array}{c}\text { West } \\
\text { Section }\end{array}$ \\
\hline $\mathrm{A}\left(\mathrm{m}^{2} / \mathrm{ped}\right)$ & 59.88 & 135.14 & 79.37 \\
\hline $\mathrm{V}(\mathrm{m} / \mathrm{min})$ & 8.695 & 7.46 & 8,00 \\
\hline $\begin{array}{l}\mathrm{Q} \\
\text { (ped } / \mathrm{m} / \text { minute })\end{array}$ & 0.145 & 0.0552 & 0.108 \\
\hline
\end{tabular}

A, V, Q is a pedestrian area, speed, and flow. Pedestrian area in all sections is more than or equal to 12 $\mathrm{m}^{2} /$ ped, so LOS for all sections is at the A level. For flow parameter, all sections have flow $\leq 6.7 \mathrm{ped} / \mathrm{m} /$ minute in LOS-A.

\subsection{Volume Capacity Ratio (VCR)}

Correlation among flow, speed, and density, based on the Greenberg model for the North section, is shown in Table 5: Vs is Velocity, D is density, and Q is flow. From the Greenberg model, the maximum flow or capacity can be calculated [17]. Pedestrian path capacity can be calculated from the equation of relationships between Q and D, or Q and Vs. Capacity is the maximum flow that can pass along the pedestrian path. Based on the Greenberg model, the capacity of the North section is $1.8056 \mathrm{ped} / \mathrm{m} / \mathrm{minute}$. Flow for the North section, based on Table 7 , is $0.145 \mathrm{ped} / \mathrm{m} /$ minute, so the VCR is 0.08 . Thus the level of service for the North section is $\mathrm{A}$.

Table 8 Relationship of Flow, Speed, and Density, based on Greenberg Model

\begin{tabular}{|c|c|c|}
\hline North section & South section & West section \\
\hline $\begin{array}{l}\text { Vs }=35.648- \\
6.718 \mathrm{LnD}\end{array}$ & $\begin{array}{l}\text { Vs }=36.694- \\
\text { 5.471LnD }\end{array}$ & $\begin{array}{l}\text { Vs }=34.935- \\
6.991 \mathrm{LnD}\end{array}$ \\
\hline $\begin{array}{l}\mathrm{Q}=35.648 \mathrm{D}- \\
6.718 \mathrm{D} \mathrm{Ln} \mathrm{D}\end{array}$ & $\begin{array}{l}\mathrm{Q}=36.694 \text { D- } \\
6.471 \mathrm{D} \mathrm{Ln} \mathrm{D}\end{array}$ & $\begin{array}{l}\mathrm{Q}=34.935 \\
\mathrm{D}-6.991 \mathrm{D} \text { Ln } \\
\mathrm{D}\end{array}$ \\
\hline $\begin{array}{l}\mathrm{Q}=0.085 \quad \mathrm{~V}_{\mathrm{s}} . \\
\mathrm{e}^{-0.062 \mathrm{Vs}}\end{array}$ & $\begin{array}{l}\mathrm{Q}=0.105 \mathrm{~V}_{\mathrm{s}} . \\
\mathrm{e}^{-0.025 \mathrm{Vs}}\end{array}$ & $\begin{array}{l}\mathrm{Q}=0.091 \\
\mathrm{~V}_{\mathrm{s}} \cdot \mathrm{e}^{-0.045 \mathrm{Vs}}\end{array}$ \\
\hline
\end{tabular}

A similar calculation shows the capacity of the South and West sections is $2.06 \mathrm{ped} / \mathrm{m} /$ minute and 1.93 $\mathrm{ped} / \mathrm{m} / \mathrm{minute}$, respectively, so the VCR value for the South section is 0.03 , and for the West section it is 0.06 .
Therefore the LOS of the South and West sections based on VCR parameter are at level A.

\subsection{Level of Service}

Recapitulation of calculation of LOS for the pedestrian path at Pasar Gede market is shown in Table 9. Based on pedestrian movement all sections have level A, but based on pedestrian path facilities (Western Australian Standard) the level of service varies within sections.

Table 9. LOS value of pedestrian path at Pasar Gede market

\begin{tabular}{lccc}
\hline Section & \multicolumn{3}{c}{ Regulation } \\
& \multicolumn{3}{c}{ Peraturan Menteri Perkerjaan Umum } \\
Nomor : 03/PRT/M/2014
\end{tabular}

\subsection{Comfort level of Pedestrian Path Facilities}

Pedestrian path facilities in Pasar Gede market are not uniform: for example, width, cleanliness, smell etc. For this reason, the analysis is divided into West, North, and South sections. The data from respondents who pass the

West section are described in Table 10. The responses are: not at all good (NG); slightly good (SG); moderately good (MG); very good (VG); and extremely $\operatorname{good}(\mathrm{EG})$.

Table 10. Score weight for West Section pedestrian path at Pasar Gede Market 


\begin{tabular}{|c|c|c|c|c|c|c|}
\hline & $\begin{array}{c}\text { Pedestrian } \\
\text { Path } \\
\text { Facilities } \\
\text { Condition } \\
\end{array}$ & NG & SG & MG & VG & EG \\
\hline 1 & Circulation & 1 & 14 & 189 & 100 & 5 \\
\hline 2 & $\begin{array}{l}\text { Weather } \\
\text { (temperature, } \\
\text { moisture) }\end{array}$ & 2 & 66 & 120 & 88 & 0 \\
\hline 3 & Noise & 2 & 62 & 150 & 50 & 5 \\
\hline 4 & Smell & 6 & 58 & 120 & 84 & 0 \\
\hline 5 & $\begin{array}{l}\text { Landscape } \\
\text { furniture }\end{array}$ & 0 & 8 & 183 & 112 & 20 \\
\hline 6 & $\begin{array}{l}\text { Safety from } \\
\text { crime }\end{array}$ & 1 & 8 & 150 & 136 & 40 \\
\hline 7 & $\begin{array}{l}\text { Safety of } \\
\text { pedestrian } \\
\text { path (slippery, } \\
\text { sloping, pot } \\
\text { hole) }\end{array}$ & 0 & 14 & 150 & 144 & 25 \\
\hline 8 & $\begin{array}{l}\text { Cleanliness of } \\
\text { pedestrian } \\
\text { path }\end{array}$ & 0 & 28 & 150 & 128 & 5 \\
\hline 9 & $\begin{array}{l}\text { Appearance } \\
\text { of landscape } \\
\text { furniture }\end{array}$ & 0 & 6 & 162 & 152 & 10 \\
\hline \multirow[t]{3}{*}{10} & $\begin{array}{l}\text { Completeness } \\
\text { of supporting } \\
\text { facilities }\end{array}$ & 0 & 48 & 165 & 62 & 10 \\
\hline & Mean & 1 & 31 & 155 & 106 & 12 \\
\hline & & $\begin{array}{c}0.4 \\
\%\end{array}$ & $\begin{array}{l}10 . \\
2 \%\end{array}$ & $\begin{array}{c}50.8 \\
\%\end{array}$ & $\begin{array}{l}34 . \\
8 \%\end{array}$ & $\begin{array}{c}3.8 \\
\%\end{array}$ \\
\hline
\end{tabular}

Based on all pedestrian path facility conditions only $0.4 \%$ of respondents stated Not at all Good, $10.2 \%$ stated Slightly Good, 50.8\% stated Moderately Good, 34.8\% stated Very Good, and 3.8\% stated Extremely Good. The highest mean plot (Table 6) thus concludes that pedestrian perception of the pedestrian path categories is one of moderate discomfort. A similar step is done for other sections.

Table 11. Pedestrian perception of pedestrian path at Pasar Gede market

\begin{tabular}{cccc}
\hline No & $\begin{array}{c}\text { Pedestrian Perception on } \\
\text { Pedestrian Path }\end{array}$ & Score (\%) & Value \\
\hline 1 & West section & $50,8 \%$ & $\begin{array}{c}\text { Moderately } \\
\text { discomfort }\end{array}$ \\
\hline 2 & North section & $48.7 \%$ & $\begin{array}{r}\text { Moderately } \\
\text { discomfort }\end{array}$ \\
\hline 3 & South section & $49,4 \%$ & $\begin{array}{c}\text { Moderately } \\
\text { discomfort }\end{array}$ \\
\hline
\end{tabular}

\subsection{Discussion}

Performa and user's perception are different things, but they should be considered simultaneously within an infrastructure facility planning. Ideally, the LOS standard of a facility also meets with user perception, in order to guarantee that the planners' valuation similar with user perception of a facility performance.

As far as author know there is not an equity comparison on LOS and User perception yet. This study also does not want to make a comparison on it, but shows that there is different between LOS and user's perception valuation on a facility when in a LOS standard only consider the pedestrian flow characteristic (Indonesia and Bangkok standard).

This study also analyzes the LOS of Australian's standard, it has been considered the physical characteristics, location factors, and users factors. Pedestrian volume is the only variable of pedestrian flow characteristic that is considered. It will show how much the different value between Australian's standard and the user perception.

The pedestrian path is an important transportation facility to support the performance of the road network, transit areas, commercial areas, residential areas etc. Factors that influence pedestrian perceptions of pedestrian paths normally have different weights for each transportation facility: e.g. the pedestrian considers the travel time of the road network and transit area, whereas for the commercial area pedestrians pay much more attention to the physical characteristics of the pedestrian path. This study compares the standard LOS for pedestrian path and road user perception in a commercial area.

Based on the regulations of Indonesia and Thailand, the LOS of the pedestrian path for all section at Pasar Gede market is in level A, but pedestrian satisfaction is "moderately discomfort." However, based on Western Australia guidelines for the West, North, and South sections, the LOS is $\mathrm{A}, \mathrm{B}$, and $\mathrm{C}$.

\section{Conclusion}

In commercial areas, Pasar Gede Market, the pedestrian path has LOS-A based on the Ministry of Public Works Regulation of No. 03/PRT/M/2014, but the user satisfaction is "moderately discomfort". This study could be the one information that there is different valuation between planners and pedestrian, so it is needed to analyze the valuation of the weight of the pedestrian flow characteristic performance and the weight of pedestrian's perception on a convenience matter. Finally these two main variable, -pedestrian flow characteristic performance and pedestrian's perception-, should be the main variables of LOS, so the planners have the similar valuation with pedestrian for a LOS on a pedestrian path.

\section{REFERENCES}

[1] World Health Organization, Health economic assessment tools (HEAT) for walking and for 
cycling: Methodology and user guide (2014 update), Economic Assessment of Transport Infrastructure and Policies, ISBN: 978-92-8900251-6, WHO Regional Office for Europe Scherfigsvej 8 DK-2100 Copenhagen Ø, Denmark, (2014)

[2] Olabarria, M, et al., Health impact of motorized trips that could be replaced by walking, European Journal of Public Health, 23(2), 217-222. doi:10.1093/eurpub/cks015 (2013)

[3] A. Polus, J.L. Schofer, A. Ushpiz, Pedestrian flow and level of service, Journal of Transportation Engineering, Vol. 109 No. 1 January (1983)

[4] Z. Ashadi-Shekari, M. Moeinaddini, M.Z. Shah, $A$ Pedestrian level of service method for evaluating and promoting walking facilities on campus streets, Land Use Policy 38, 175 - 193 (2014)

[5] L. Kang, Y. Xiong,, F.L. Mannering, Statistical analysis of pedestrian perceptions of sidewalk level of service in the presence of bicycles. Journal of Transportation Research Part A 53, 10-21 (2013)

[6] S. Jena, Perception based pedestrian level of service, Thesis for diploma in Department of Civil Engineering National Institute of Technology Rourkela, India.

[7] P. Christopoulou, M. Pitsiava-Latinopoulou, Development of a model for the estimation of pedestrian level of service in Greek urban areas, Procedia - Social and Behavioral Sciences 481691 - 1701 (2012)

[8] Singh K., Jain P.K., Methods of assessing pedestrian level of service, Journal of Engineering Research and Studies Vol II January-March -116124, E-ISSN 0976-7916 (2011)

[9] F. R. Sutikno, Surjono, E. B. Kurniawan, Walkability and pedestrian perceptions in Malang City emerging business corridor, Procedia Environmental Sciences 17424 - 433 (2013)

[10] N. Hidayat, K. Choocharukul, K. Kishi, Pedetrian level of service model incorporating pedestrian perception for sidewalk with vendor activities, Proceedings of The Eastern Asia Society for Transportation Studies, 8 (2011)

[11] Ministry of Public Works, Regulation of Ministry of Public Works No. 03 / PRT/ M / 2014 (2014)

[12] Y. Tanaboriboon, J. A. Guyano, Level-of-Service Standarts for Pedestrian Facilities in Bangkok, ITE Journal, November, pp. 39 - 41 (1989)

[13] Government of Western Australia, Guidelines For
Assessing Pedestrian Level Of Service, Western Australia (2006)

[14] Fika I. Pratiwi, Studi Karateristik Pergerakan Pejalan Kaki Di Pedestrians Road Stasiun Tugu Yogyakarta, Thesis for Undergraduate UGM, Yogyakarta (2011)

[15] R. Hakim, H. Utomo, Komponen Perancangan Arsitektur Lansekap, Bumi Aksara, Jakarta (2003)

[16] Sugiyono, Metode Penelitian dan Pengembangan, Alfabeta, Bandung (2015)

[17] O. Z. Tamin, Perencanaan Pemodelan dan Rekayasa Transportasi, Teori contoh soal dan aplikasi, ITB Publisher, Bandung (2003)

Corresponding author: amirotulmhm@staff.uns.ac.id 